\title{
The Ethical Dimension in Political Market Orientation: A Framework for Evaluating the Impact of India's Look East Policy on Regional Income Convergence
}

\author{
Homagni Choudhury $^{1} \cdot$ Zoltan Laszlo Kopacsi $^{1} \cdot$ Gunjan Saxena ${ }^{2} \cdot$ Nishikant Mishra $^{2}$
}

Received: 17 May 2018 / Accepted: 26 April 2019 / Published online: 28 May 2019

(c) The Author(s) 2019

\begin{abstract}
In this paper, we employ what we term as 'the ethical dimension in political market orientation (PMO)' framework to underline how an integration of information from relevant stakeholder groups can inform the formulation of market-oriented, yet ethical policies. Against the backdrop of India's Look East Policy (LEP), we undertake a critical analysis of historic economic data from 1980 to 2014 in the states of Arunachal Pradesh, Assam, Manipur, Meghalaya, Mizoram, Nagaland and Tripura, often termed as the Seven Sisters because of their interdependence. Our analysis of the data, using time-series methods, reveals that policy changes ensuing from the economic reforms of 1990s and the initiation of the LEP in 1991 have resulted in regional income convergence in North-Eastern India. A key contribution of our work emanates from the fact that we determine two structural breaks endogenously from long time-series data, thereby identifying three distinct policy regimes, rather than specifying exogenous breaks based on historic and theoretical conjectures. Overall, our work offers both conceptual insights into processes that enable ethical and inclusive policy making, as well as empirical evidence emerging from stochastic convergence of incomes per capita for the Seven Sister states in the North-Eastern region in India, to illustrate how regional economic inequality can be reduced through targeted market-oriented policies.
\end{abstract}

Keywords Look East policy $\cdot$ Ethical policy making $\cdot$ Political market orientation $\cdot$ Regional inequality $\cdot$ Stochastic convergence $\cdot$ Structural breaks

Electronic supplementary material The online version of this article (https://doi.org/10.1007/s10551-019-04169-w) contains supplementary material, which is available to authorized users.

Homagni Choudhury

H.Choudhury@kingston.ac.uk

Zoltan Laszlo Kopacsi

K1746670@kingston.ac.uk

Gunjan Saxena

G.Saxena@hull.ac.uk

Nishikant Mishra

Nishikant.Mishra@hull.ac.uk

1 Department of Economics, Kingston University, Penrhyn Road, Kingston upon Thames, Surrey KT1 2EE, UK

2 Faculty of Business, Law and Politics, University of Hull, Cottingham Road, Hull HU6 7RX, UK

\section{Introduction}

This paper examines how India's Look East Policy (LEP), originally focused on building institutional linkages with the Association of Southeast Asian Nations (ASEAN) and strengthening bilateral relations with its member states, also resulted in income convergence in its North-Eastern Region (NER). The launch of the LEP (1991-2014) coincided with a range of economic reforms starting in 1991 and resulting from a combination of factors - the collapse of India's valued economic partner, the Soviet Union and severe financial crisis along with a growth in globalisation (Bhaumik 2014; Sikri 2009; Choudhury 2010, 2012). It should be noted that whilst the LEP was not a direct product of comprehensive economic and structural reforms of 1990s (like other policy changes, e.g. trade liberalisation and industrial reforms), it emerged as an ancillary policy response at a time that saw India opening up to the world in the 1990s. Officially launched in 1991, the LEP, together with the macro and structural reforms of the $1990 \mathrm{~s}$, brought about a paradigm 
shift, unleashing private enterprise that engendered radical economic transformation (Haokip 2011).

We examine this shift through the conceptual lens of political market orientation (PMO) (see Ormrod 2005; Ormrod and Henneberg 2009), focusing in particular on what we consider the ethical dimension in PMO, to argue that marketoriented policies are both dynamic and contribute to ethical policy making, as they are informed by the values of relevant stakeholder groups (Freeman et al. 2004, 2007). Our work is one of the first to engage with the domestic dimension of the LEP (i.e. its impact on regional income convergence in the context of India's NER). Indeed, on one hand, market-based reforms initiated in 1991 resulted in significant reductions in tariff and non-tariff barriers, the pruning of public sector monopolies, and an easing of the inflow of foreign direct investment. On the other, they led to an ethical reframing (i.e. by taking stock of the importance of non-materialist aspirations such as inclusion, citizenship and community) of economic policy, which acquired a more human face for the local populace. The emphasis moved towards gaining a deeper understanding of issues such as access, inclusion, equity and social justice in the sub-regional connectivity projects, aimed at improving the economic integration of the NER with national and international markets of South and South-East Asia (Ziipao 2018).

In order to grasp the impact of the LEP on the unconnected and underdeveloped communities of the NER, we employ a unified analytical framework that combines the theoretical context informed by political market orientation (PMO) with an empirical approach embedded in work on income convergence from the regional economics literature. Our cross-disciplinary analysis of historic economic data (1980-2014) $)^{1}$ provides unique insights into the impact of the LEP on regional convergence of incomes in the NER. Although the 1980s precede the LEP, we include data from this time period for it acts as the benchmark (i.e. pre-policy intervention phase), allowing us to gauge the deep-seated nature of economic reforms and the impact of policy interventions since the 1990s on income convergence in the long run. In fact, it will not be unfair to regard the 1980s as constituting a 'policy void' in the region (see Das 2010). During this phase, India relied on a strategy of import substitution industrialisation (ISI), that saw significant tariff and non-tariff protection as well as industrial licensing, which favoured larger industrialised states and bypassed the peripheral economy of the NER. ${ }^{2}$ Thus, having the 1980s as the

\footnotetext{
1 The data we use are based on financial years from 1980-81 until 2014-2015, but for brevity we refer to this time period as 1980-2014 in the rest of the paper.

${ }^{2}$ Economic policies prior to 1991 were more favourable towards states in mainland India (ignoring the peripheral NER states). For example, heavy industries were supported in larger states like Karnataka (Hindustan Aeronautics Limited-HAL was set up in 1964
}

basis for our empirical analysis allows us to understand the regional income dynamics better and to empirically capture the long-term processes of income convergence. ${ }^{3}$ Against this backdrop, the specific research questions examined in this paper are as follows:

- What are the key insights provided by the ethical dimension in PMO in theorising the strategic role and the influence of key stakeholders in the LEP's implementation processes?

- Did the LEP contribute to improving the economic performance of the NER, as captured through any evidence on regional income convergence?

- What strategic lessons can be derived from the LEP's impact on income convergence?

These questions enable us to engage with the LEP's domestic development angle, which gained precedence as policy makers began to view its political potential in bringing about an improved connectivity of the NER's rural underdeveloped areas with the rest of India, and as means of closing the income gap between the region and the rest of India. We use the notion of stochastic convergence that tests, through a time-series methodology and using historic data from 1980 to 2014, whether there is statistical evidence of the lagging Seven Sisters of the NER catching-up with the rest of India in the long run, in order to ascertain the concurrent impact of the LEP and market reforms. The theoretical frame afforded by the PMO helps us to gauge dynamic socio-economic processes evolving over time as a result of reform-oriented policies, shaped by the values of a range of stakeholders and

Footnote 2 (continued)

by the government of India in Bangalore and continuously expanded operational facilities in Andhra Pradesh, Maharashtra and Uttar Pradesh, through the 1970s and 1980s), Orissa (National Aluminium Company Limited-NALCO was set up in 1981), Delhi (Bharat Heavy Industries Limited-BHEL was first set up in Delhi in 1964 and its manufacturing facilities were expanded to other Indian mainland states including Andhra Pradesh, Madhya Pradesh, Karnataka, Uttar Pradesh and other states throughout the 1970s and 1980s). Similarly, green revolution initiated in the mid- to late-1960s mainly targeted and benefitted North and North-Western states like Punjab, Haryana and Uttar Pradesh throughout the 1970s and 1980s.

${ }^{3}$ Income convergence in economics is a long-run phenomenon, which requires long time-series data to be captured appropriately. Our data include a pre-liberalisation period (1980s) and a post-liberalisation period (1990s and 2000s), which makes it possible to test for income convergence in the long run, and to capture the effect of reforms (macro and structural reforms in the 1990s for all states in India and implementation of the LEP in the 2000s for the states in the NER) through structural breaks in our income convergence tests (see, Chatterji and Choudhury 2013). Additionally, long time-series increases the statistical power of the tests employed in this paper to account for structural breaks, making the results more robust and reliable (Choudhury and Hawes 2014). 
their interface (Bathelt and Glückler 2003, 2011; Pandey and Gupta 2016).

\section{Conceptual Framework}

\section{Political Market Orientation}

We employ key tenets of the PMO framework (see Ormrod 2006, 2014; Ormrod and Henneberg 2009; Ormrod and Savigny 2011) to theorise multi-faceted-political, strategic and economic-stakeholder relationships impacting upon the LEP. Broadly, the research on market orientation (MO) provides the conceptual basis for PMO (see Jaworski and Kohli 1993; Kohli et al. 1993; Narver and Slater 1990). The term MO, first coined by Levitt (1960), denotes a set of norms focused on assessing and acting on customers' needs, plus predicting and responding to competitors' conduct, to exploit opportunities and circumvent threats (Kohli and Jaworski 1990; Morgan and Strong 1998). We consider the PMO appropriate in the context of our work due to the inadequacy of the MO concept to engage with and address long-term stakeholder interests because of an overemphasis on maximising short-term profitability (Kirca et al. 2005). In contrast, the PMO helps to engage with the impact of market-oriented policies on various stakeholders, as well as map the resulting progress towards responsible democratic governance. In fact, by adopting the PMO perspective in examining the market-oriented policy focus of the LEP aimed at opening up of the economy, we respond to authors' call for a need to integrate political science and marketing research streams (see Coleman 2007; O'Cass and Voola 2011; Wring 1997).

Indeed, the PMO allows a deeper understanding of how policies leverage their marketing acumen for the welfare of relevant stakeholders. The main emphasis of Ormrod's (2005) conceptualisation of PMO lies in the significance it accords to political party members' values and their orientation towards specific stakeholder groups. Thus, from this perspective, a PMO is conceived to exist:

... when all members of a party are sensitive to internal and external stakeholders' attitudes, needs and wants, and synthesise these within a framework of constraints imposed by all stakeholders to develop policies and programmes with which to reach the party's objectives (Ormrod 2005, p. 51).

This conceptualisation facilitates a link between two research areas of political marketing and societal marketing (see Fig. 1). In the context of our focus on the market-oriented dimension of the LEP, we extend Ormrod's definition to include both party and policy objectives, respectively. We argue that the successful implementation of a party's agenda or a policy affects (and is affected) by a multitude of meso-, micro- and macro-level stakeholders, not just voters (Bhattacharya and Korschun 2008; Fritzsche 1991; Hoeffler and Keller 2002). Indeed, as we demonstrate in our analysis, the LEP's multi-faceted and multi-pronged approach to establish strategic links with macro-level stakeholders such as ASEAN (Association of Southeast Asian Nations) members worked in conjunction with a greater sensitivity towards and a focus on strengthening meso- and micro-level bodies in the NER such as the State Governments, the NGO sector and the grassroots level groups (Naidu 2004).

In general, Ormrod's $(2005,2007)$ PMO model consists of eight constructs-four being attitudinal and the other four behavioural (see Table 1). Together, attitudinal and behavioural constructs serve as means to engage with different stakeholder groups in bringing about the execution of market-oriented policies as summarised in Fig. 1. The emphasis on addressing the needs of a variety of stakeholders and securing the best possible outcomes for them constitutes what we regard as 'the ethical dimension in PMO' (see Fig. 1). Thus, the Internal Orientation (IO) is inclusive, as policy goals and/or party agenda are disseminated to members irrespective of their rank within the party. Whilst the Voter Orientation (VO) is responsive, as policies respond to and are guided by the needs of the general public, the Competitor Orientation (CO) is characterised by resilience, as any policy success is dependent on stakeholders' support and their commitment to execute market-oriented policies despite a regime change. Stakeholder Orientation (SO) towards meso-level stakeholders is one of adaptive collaboration, for they not only influence the policy outcome, but can also provide valuable feedback at the policy formulation stage. The macro-level stakeholders add value and extend the reach of policies and/or a party's vision, a compliance with micro-level stakeholders' priorities contributes to their capacity building and participation.

As such, we extend the theoretical understanding around PMO to regard it as composite of stakeholders' values and concerns that provide an overarching thrust towards marketoriented policies, which are both progressive and ethical. We consider what we conceptualise as 'the ethical dimension in PMO' (Fig. 1) to engage with processes underlying the market-oriented nature of policy making. Our theorising of the ethical dimension in PMO foregrounds the need for an emphasis on a longer term and more permanent strategic relationship-building with key stakeholders operating at different levels, as opposed to short-term tactics aimed at conducting market research (often prior to an election) to identify voters' priorities. Indeed, the LEP, by focusing on dynamism — both at domestic and regional levels—engaged with a multitude of societal actors, not just voters (Jaffrelot 2003). In fact, the market-oriented policy ethos inherent in the LEP helped dilute partisan preferences in favour of 
Fig. 1 The ethical dimension in PMO. Source Adapted from (Ormrod 2014; Ormrod and Henneberg 2009). Notes SO stakeholder orientation

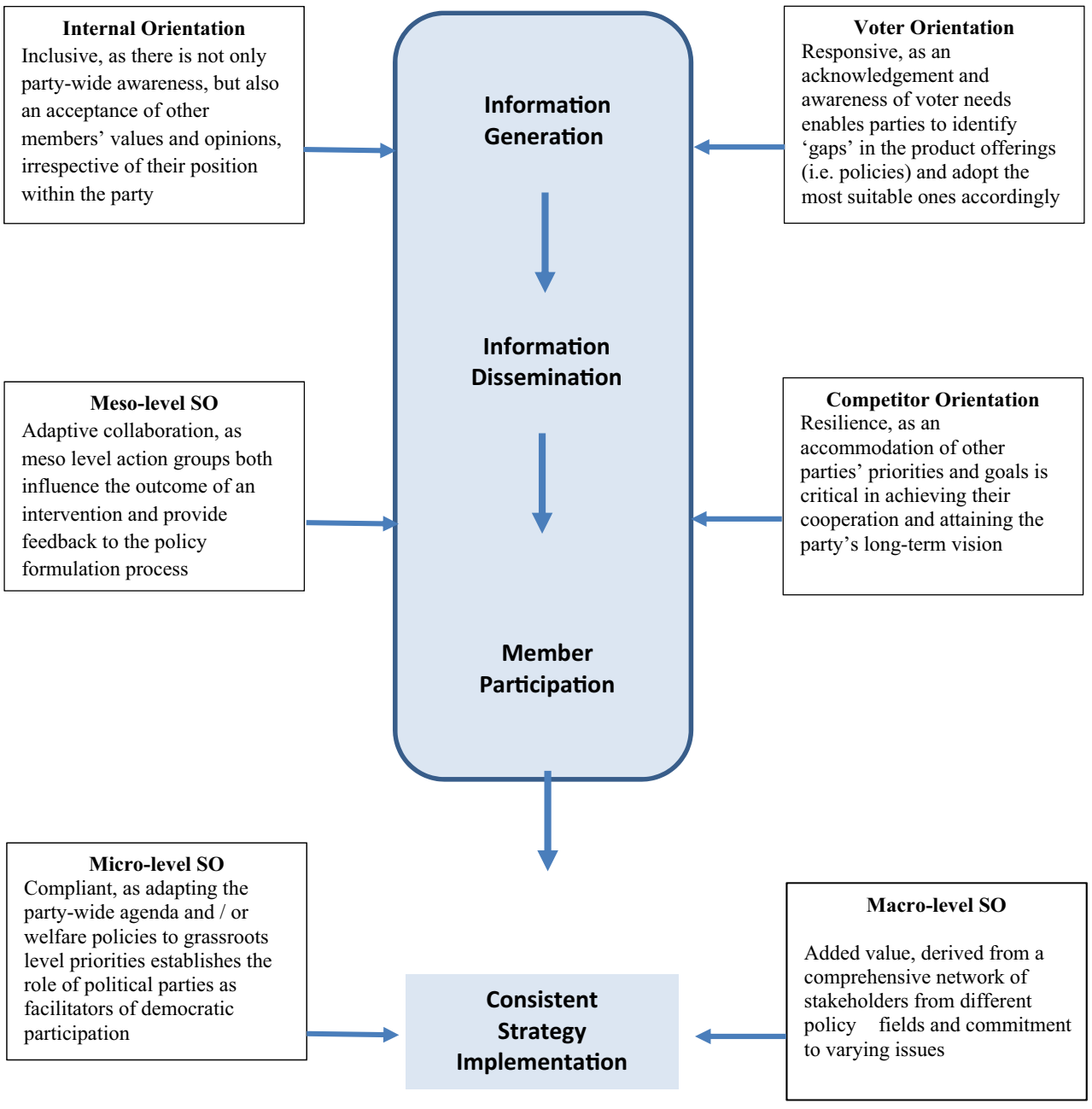

policies that were inclusive and informed by stakeholders' concerns.

\section{The Ethical Dimension in PMO and the Market-Oriented Thrust of the LEP}

The ethical dimension in PMO is well suited to serve as the conceptual basis for engaging with the market-oriented thrust of the LEP, due to the framework it offers in engaging with multiple stakeholders and reach a synthesis within the context of constraints imposed by them to develop policies and programmes that are capable of addressing long-term developmental goals. Indeed, the LEP provided the Indian government and, to a lesser extent private Indian corporations, an integrated approach to infuse the NER's sluggish economy with dynamism resulting in lucrative contracts for industrial and infrastructure projects, including the construction of highways, pipelines and ports (Goldberg 2017). Further, in order to engage with the LEP's wider orientation towards society, we consider two related sub-constructs (following O'Cass and Voola 2011)—proactive political market orientation (PPMO) and reactive political market orientation (RPMO).

Our contention is that market-oriented policies, which are PPMO-driven, are more likely to address not only the expressed, but the latent needs of the electorate in a region, due to their better fit with priorities and preferences of lead stakeholders. Also, they are capable of driving the market by "... trying to actively convince others of the beneficial nature of the political offer" (Henneberg 2006, p. 31). Since PPMO involves researching and imagining latent needs through a "probe-and-learn" process, policy making is dependent upon and is informed by a broad range of sources that enable it to overcome prior limitations, as well as engage in experimentation in order to formulate creative solutions to issues (Atuahene-Gima et al. 2005). It is no coincidence that the initiation of the LEP overlapped with wider pro-market macro and structural reforms of the 1990s aimed at improving the NER's economic competency and productivity. Indeed, the emphasis of the LEP to link the NER's rural belt-especially, facilitating the connectivity of local markets-with regional, national and international markets, helped the 
region to emerge as a strategically crucial region (Ziipao 2018). The PPMO thrust of the LEP and the wider reforms of the 1990s resulted in significant competitive advantage for the NER, because of its focus on continually improving productivity and efficiency to facilitate the region's 'catchingup' process with the national economy.

In contrast, the RPMO is a damage-repair strategy and is put into place to either ward off the potential negative effects of past policies or implement change until it is absolutely necessary (see Barney 1991 for similar reasoning in commercial context). Thus, it is ad hoc in nature and activated (often without prior debate and consultation) in response to a crisis, with an emphasis on how policy mechanism can best handle the fallout from unpopular policies (Banks, 1999). Authors describe crisis situations variously as "windows of opportunities" (Kingdon 1964, p. 62) or "critical junctures" (Capoccia and Kelemen 2007, p. 341) that can be exploited politically to push forward radical reforms. To a large extent, the LEP was implemented in response to a crisis, namely as a measure to alleviate various kinds of social, economic and political handicaps of the peripheral and landlocked NER (Srikanth 2016). There was a lack of consensus on policy outcomes and a resource scarcity, resulting in tradeoffs between conflicting demands and priorities (Lindblom 1980). Nevertheless, the acceleration in implementing the development-oriented thrust of the LEP in the 2000s paved the way for infrastructure development within the NER and opened up possibilities for sub-regional cooperation with neighbouring countries (Ziipao 2018).

In general, we underline the complementary nature of both PPMO and RPMO that together contribute to sustaining the ethical dimension in the PMO and in bringing about the competitive advantage of a region (O'Cass and Voola 2011; Reid 1988). The ethical dimension in PMO affords 'legitimacy' to different stakes (including the ones of the less powerful stakeholders) and the fact that even if various groups are not necessary for the implementation of market-oriented policies, three critical elements-power, legitimacy and urgency (Mitchell et al. 1997)_pertaining to stakeholders are critical to their long-term success. Whilst power refers to their influence over others, legitimacy relates to values, norms and patterns of behaviour that define stakeholders who have a claim or interest in market-oriented policies, and urgency serves as the catalyst that brings about a debate and possible conflict resolution in the policy implementation processes (Maignan et al. 2007).

We now consider the LEP's domestic dimension, focusing on how market-oriented reforms resulted in new 'product offerings' (i.e. policies) that facilitated the income convergence in the NER. We employ the ethical dimension in PMO (encompassing both PPMO and RPMO) to illustrate the LEP's impact on the lagging economies of Seven Sisters. 


\section{Background, Context, Methodology and Data}

\section{The LEP and the NER}

The economically lagging NER's only land link with the rest of India is through a narrow sliver of land-“"the 'Chicken's Neck' near Siliguri” (Kathuria 2017)—due to Bangladesh's reluctance to give transit facilities to India. ${ }^{4}$ Thus, one of the key focus areas of the LEP was to intensify the region's economic links with Myanmar and other Southeast Asian countries, in order to reduce its overwhelming dependence on Bangladesh. In fact, the NER is considered as India's gateway to Southeast Asia, as it shares 98 per cent of its border with Myanmar, Bangladesh, China, and Bhutan, and has transport and trading corridors present at various border points (Toppo 2016). This makes the NER strategically significant and vital not only for India's future economic growth, but also for its aspirations to assume global leadership.

Given this context, the state governments of Seven Sisters, hitherto excluded from the decision-making process, were recognised as key stakeholders in the larger Asian integration process. The vision document for the LEP expressly vocalised its commitment to elevate their economic status through alleviating poverty and reducing inequality. In fact, under the classification of Special Category States status, the NER has benefited from generous Government of India (GOI) funding. The per capita gross disbursement of central assistance by the GOI in 2012-2013 was Rupees 13,325.77 for the NER, as compared with Rupees 7047.47 in other states (Bhattacharya 2014). Since 2000, 49 new National Highways have been initiated in the NER, which are now at various stages of completion (Sangwan 2016). In fact, within the development discourse in the NER, infrastructure provides a basis for gaining an understanding of, and acting upon issues of access, inclusion, equity and social justice (Ziipao 2018).

Since the local populace at large (e.g. residents, non-profit sector and the wider business community) was set to benefit from the LEP and had a significant stake in its effective implementation, it acquired the status of a key stakeholder. A number of projects in horticulture, fisheries and livestock (which still continue) were sponsored with a view to

\footnotetext{
${ }^{4}$ This is set to change as close cooperation between Bangladesh and India (including various ongoing initiatives such as the transshipment of Indian goods through Bangladesh's Ashuganj port to Northeast India, the expansion of rail links within Northeast India and between the two countries as well as the BBIN Motor Vehicles Agreement), as part of the broader LEP initiative, is set to dramatically reduce the cost of transport between the NER and the rest of India.
}

generate income and jobs in the region. The Department of Development of the North Eastern Region (DONER), set up by the GOI in September 2001, was accorded the status of a full-fledged ministry in May 2004, to act as a facilitator between the central government and the state governments of the NER. The aim was that it would accelerate the pace of socio-economic development in the region, so that it may enjoy growth parity with the rest of the country (Planning Commission, GOI 2013). Additionally, the North Eastern Council (NEC), first established in 1971 through the North Eastern Council Act of 1971, was elevated from an advisory body to a full-fledged 'regional planning body' in 2002 through the North Eastern Council (Amendment) Act of 2002. The NEC has played a crucial role in raising the profile and accelerating the implementation of the LEP for the benefit of the NER in the 2000s, as reflected in the NER Vision 2020 policy document, published jointly by the NEC and Ministry of DONER in 2008. Further, in a bid to support local agency and enterprise, the Reserve Bank of India (RBI) constituted a committee known as the Financial Sector Plan for the NER in 2006, to strengthen linkages between banks and self-help groups. The entrepreneurial nature of this model and the extensive use of information technology to facilitate off-site banking were instrumental in securing finance for small firms and start-ups (Sangwan 2016).

Additionally, since the establishment of commercial links between the NER and neighbouring states of Myanmar and Bangladesh were crucial to engage in and benefit from international trade, therefore foreign governments were also recognised as key stakeholders. The LEP facilitated India's involvement in a variety of cross-border development projects with Myanmar, Thailand, Bhutan and Vietnam in diverse fields such as roads, railways, telecommunications, IT, science and technology and power (Das 2010). With time, as India acquired credibility as a rising Asian power and an important potential economic partner, the LEP elicited a serious response from ASEAN and other East Asian countries (Sikri 2009). For instance, in 2002, India became a Summit-level Dialogue Partner of ASEAN and implemented steps to establish free-trade agreement in goods, services and investment over the next decade. Thus, the LEP not only strengthened India's relationship with ASEAN, but also facilitated the country's bilateral ties with individual ASEAN countries, promoting greater awareness of the potential for trade, tourism and micro-level ties.

In general, the LEP appeared to be guided by the ethical dimension in PMO (see Fig. 1), with the potential to act as a bridge between stakeholders and proved instrumental in engaging both the local populace and state governments. However, fiscal indiscipline, abysmal levels of corruption and misappropriation of funds limited its impact (Chatterjee 2014). The LEP ended up benefiting large traders, industrialists and highly qualified professionals, rather than resulting 
in widespread employment generation (ICWA 2015). Also, the lack of sustainable and equitable benefit-sharing and consistent dialogue between the NER state governments weakened the acceptance of the LEP as a long-term strategy aimed at bringing about market reforms (Naidu 2001). On the foreign front, the macro-level SO of the LEP provided the basis for the consolidation of India's ties with its neighbours, with a particular emphasis on economic growth. However, for foreign regimes, India's failure to spell out its interests, concerns and strategic stakes resulted in considerable confusion, especially in Southeast Asia (Chatterjee 2007). Despite these limitations, we argue that the LEP's grounding in the ethical dimension in PMO and its explicit reference to the importance of stakeholders in the implementation of the development agenda throughout the 2000s, indirectly resulted in a modest increase in incomes per capita in the NER.

Against this backdrop of gradual and incremental policy changes in the 1990s (macro and structural reforms and initiation of the LEP) and 2000s (implementation and intensification of specific LEP instruments targeting the development of the NER), we examine and engage with the dynamics of income convergence within the region, as well as the convergence of the region to the rest of India in terms of incomes per capita. We discuss stochastic convergence and its implications in the context of income disparity in the NER in the following section.

\section{Income Disparity in the NER}

In general, disparity in incomes per capita between regions may simply reflect differences in natural or purely economic conditions, due to differences in geography, natural endowments and infrastructural links. For the purpose of this paper, we call such differences in per capita incomes as 'compensating differentials' ${ }^{5}$ Income differentials might also arise from policy differences at the state/regional level. This works through the ability (or lack thereof) of states

\footnotetext{
5 We borrow the term 'compensating differentials' from labour economics. According to the theory of the "compensating differentials" (also called the theory of equalising differentials), individual workers are induced to accept less attractive jobs by compensating differences in their wage rates. For a review of the compensating differentials hypothesis, see Rosen (1986). In this paper, we use the term 'compensating differentials' loosely to indicate inter-state differences in state incomes due to natural or economic conditions. For example, relatively inhospitable and inaccessible terrain in Arunachal Pradesh in comparison to the fertile soils of Assam reflect natural differences between production capacities/environment between these states, which may explain differences in income per capita. We use the term 'compensating differentials' in this paper to capture such differentials in incomes per capita among states due to economic geography factors.
}

to generate rents through advantageous discretionary policies, reflected as some kind of premium (or loss) in their per capita incomes, which may either offset or complement the 'compensating differentials'.

India's ISI strategy prior to 1991 favoured larger states in the rest of India, and overlooked the peripheral NER, leading to a policy void in the region during the 1980 s, resulting in premiums (for larger states) and/or losses (for NER states), respectively. In a highly protected economy, restrictive inward-looking import substitution policies and planned industrialisation through industrial licensing often created economic (market) distortions, and hence states would be expected to generate substantial amount of economic rents. ${ }^{6}$ In the Indian case, the bigger states in India favoured through inward-looking ISI policy in the 1980s were potentially in a position to generate greater rents compared to the peripheral, landlocked and isolated Seven Sisters that remained outside any major policy sphere, resulting in their divergence away from national trends in incomes per capita. Under such a distorted policy regime, inter-state income differences potentially reflected the varying rent-generation capacity of states, rather than true 'compensating differentials'. However, as a result of market-based economic reforms, including trade liberalisation and industrial deregulation, state rents experienced a decrease and inter-state income per capita differences (stochastically) converged towards 'compensating differentials' (see following section on stochastic convergence).

This process was enhanced further by additional directed and corrective policies which set the development agenda for the NER as part of the LEP in 1991 and implemented in the 2000s. In fact, the LEP embodied both PPMO, because of its role in facilitating market reforms and dialogue across sectors, as well as RPMO, as policy-change processes appeared to be implemented in an ad hoc manner without adequate consultation in response to the NER's economic crisis. Nevertheless, it served as an opportunity for stakeholders in the region to jointly work at addressing the negative impact of political neglect and embrace economic growth. Indeed, from the state income per capita perspective for each of the seven states and the NER as a whole, juxtaposed against the average Indian income per capita for the period 1980-2014, modest growth is evident (Fig. 2).

\footnotetext{
6 A distortion is any departure from the ideal economic system and it therefore interferes with the process of economic agents maximising social welfare when they maximise their own (Deardorff 2014). Rentseeking refers to all largely unproductive, expropriative activities, which bring positive return to the individual agent but not to society as a whole (Krueger 1974). Rent-seeking results in reduced economic efficiency through poor allocation of resources, reduced actual wealth-creation, lost government revenue, increased income inequality and (potentially) national decline (Dabla-Norris and Wade 2001).
} 

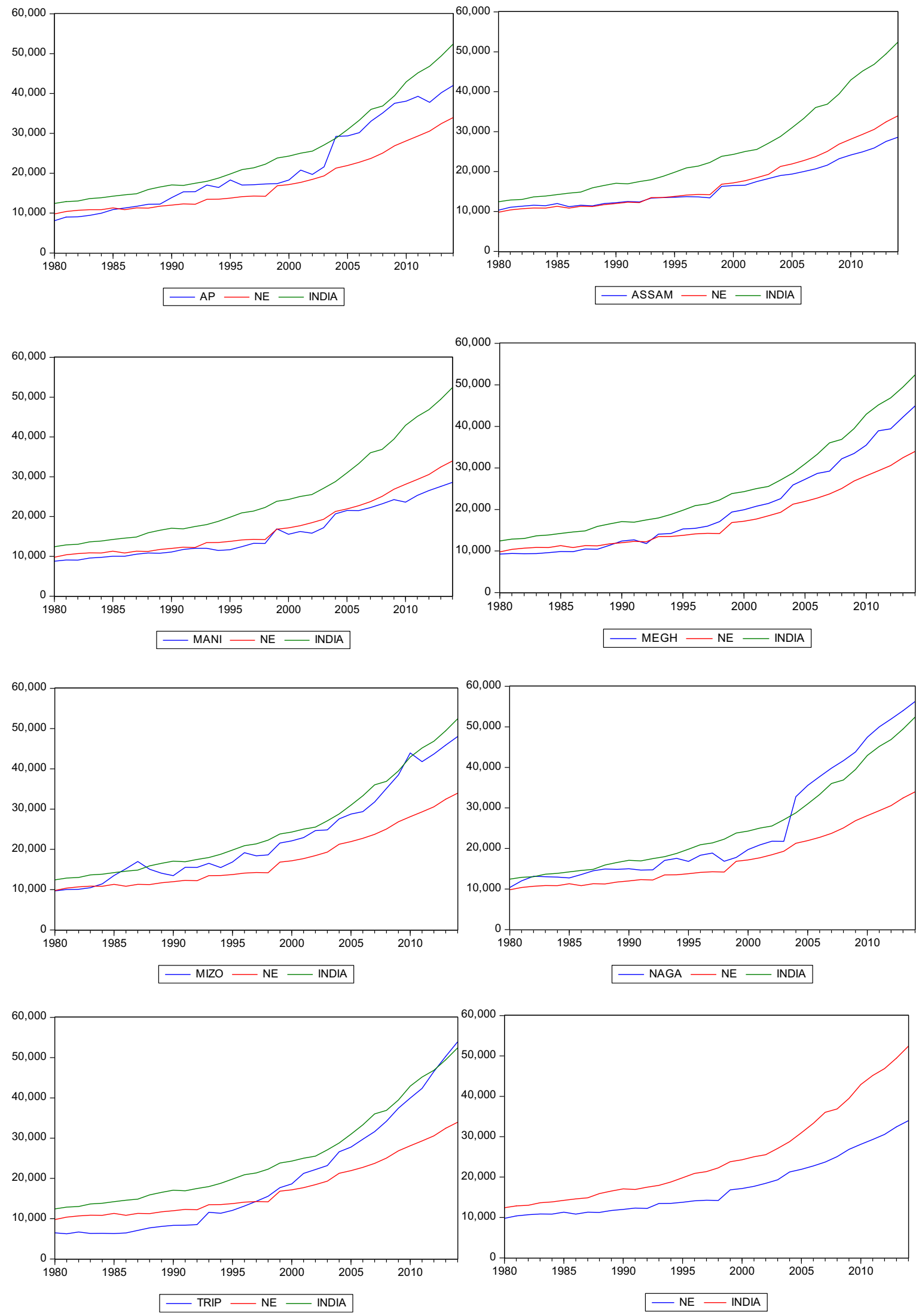
4Fig. 2 Income per capita for the Seven Sisters, NER and India, 1980-2014. Source Authors' calculations based on data from MoSPI, GoI. Notes The vertical axis measures incomes per capita in Indian rupees in constant 2004-2005 prices. The series labelled NE is the population weighted average income per capita for the NER. The series labelled INDIA is the national average income per capita for India. AP, Megh, Mizo, Naga and Trip stand for Arunachal Pradesh, Meghalaya, Mizoram, Nagaland and Tripura, respectively

Overall, the cross-comparison presents a mixed pictureon one hand, states like Arunachal Pradesh, Meghalaya, Mizoram and Tripura that started with incomes per capita below that of the all India average as well as below the NER average in 1980 ended up surpassing the NER average and advanced towards the all India average by the end of 2014. On the other hand, whilst both Assam and Nagaland started off better than the NER average, but below the Indian average in 1980, only Nagaland managed to surpass both the NER and the Indian average by the end of 2014. Similarly, Manipur that started off worse than the NER average ended up with a per capita income in 2014 that was below both the NER and the Indian average. Finally, the figure shows that the income per capita for the NER as a whole seemed to have diverged away from that of India over the period 1980-2014. This makes it imperative to statistically test for any evidence for convergence (or divergence) of incomes per capita across these states and between these states and India plus between the NER as a whole and India. This is especially crucial because the market reforms of the 1990s (including the announcement of the LEP) and the implementation of the LEP in the 2000s, embodying PPMO and RPMO, may have permanently affected the long-run time paths of incomes per capita for each individual state relative to the region as a whole as well as the national average. As such, and allowing for heterogeneity across states, we expect two state-specific structural breaks-one in the 1990s capturing the effect of PPMO embodied in the initiation of the LEP in 1991 along with structural economic reforms, and one in the 2000s capturing the effect of RPMO embodied in the implementation of various instruments of the LEP. In fact, ignoring structural breaks in our testing procedure for income convergence may result in the erroneous conclusion of stochastic divergence of state incomes per capita-a point that we elaborate further in our methodology in the following section.

\section{Methodology: Testing for Stochastic Convergence}

We make use of long historical time-series data to test for (stochastic) convergence of incomes per capita, to demonstrate the effects of the reforms and initiation of the LEP in the 1990s and the implementation of development instruments of the LEP in the NER during the 2000s, which embody PPMO and RPMO, respectively, as outlined in the preceding sections. To test for regional income convergence, the existing literature relies predominantly on crosssectional growth equations, following in the tradition established by Barro (1991) and Barro and Sala-i-Martin (1997). However, recent advances in time-series methods and the availability of long time-series data have made it possible to examine stochastic convergence of incomes, by using powerful unit root tests capturing any potential structural breaks (that can be endogenously determined from the data) caused by major socio-economic events like policy interventions of the 1990s and 2000s as described above (Chatterji and Choudhury 2013). The time-series approach to income convergence relies on a methodology proposed by Carlino and Mills (1993), who, along with Quah (1993), questioned the validity of cross-sectional studies focusing solely on beta convergence. A commonly raised objection against the cross-sectional approach is that it assumes that all states are growing at the same rate, and converging towards the same steady-state, whilst ignoring any issues which might arise from non-stationarity. Carlino and Mills (1993), in their seminal paper examining regional income convergence in the United States between eight geographical regions, tested whether relative income series were stationary, that is if they exhibited mean reversion.

This approach overcomes the limitations of cross-sectional growth equations by allowing for the presence of 'compensating differentials', which would incorporate the effects of state-specific characteristics, such as the levels of human and physical capital, infrastructure and investment, and would allow for different steady-states. Also, it does not require the strict assumption of a uniform growth rate across all states, but it addresses the problem of non-stationarity through stochastic convergence. This is because even if per capita incomes within a country exhibit beta convergence yet stochastic divergence, as would be evidenced by the presence of a unit root in the relative series, then even though poorer states are growing faster than richer ones, any exogenous shocks would lead to a persistent income differential, preventing 'true' convergence.

Our methodology of testing for "stochastic convergence" of incomes per capita for the NER states in India therefore follows the time-series methodology suggested in Carlino and Mills (1993). ${ }^{7}$ In the case of individual states, we consider the convergence of per capita state incomes vis-à-vis population weighted average income in Seven Sisters and the national average of income per capita. In the case of

\footnotetext{
${ }_{7}$ We outline a more technical exposition of the stochastic income convergence approach and our methodology to test for stochastic convergence in a separate Online Appendix, as suggested by one of the anonymous referees for the paper.
} 
the NER as a whole, we consider the convergence of the seven states' population weighted average per capita income converging to the Indian average per capita income. In the case of individual states, "stochastic convergence" implies that shocks to incomes per capita in any state " $s$ " relative to the average income per capita in all seven states, will be temporary. For each of the seven states " $s$ ", we examine the null hypothesis that real income per capita are diverging and test for a unit root in the log of the ratio of real income per capita relative to the population weighted average income per capita for the seven states. A failure to reject the unit root null provides evidence against convergence of incomes per capita among states. In this case, following a shock to relative real income per capita in state " $s$ " there is no tendency for real income per capita to return to the (weighted) average, which would imply that state incomes diverge.

In contrast, the rejection of a unit root supports the alternative hypothesis that shocks in relative incomes per capita are temporary, which implies that incomes converge. If we include a constant term in the test, then stochastic convergence (as described above) implies that real incomes per capita converge to a state-specific 'compensating differential', meaning that stochastic convergence is consistent with 'conditional convergence' (Strazicich et al. 2004). To test if the Seven Sisters are converging to the Indian average, we examine the same null, but in this case, use the log of the ratio of real income per capita relative to the Indian average. Whilst to test for the convergence of the entire NER to the Indian average, we rely on the log of the ratio of the sevenstates population weighted average real income per capita relative to the Indian average instead.

To perform our tests for stochastic convergence, we consider the time-series characteristics of three different relative income series $-Y_{1}$, capturing the relative income of an individual state to that of the NER average; $Y_{2 t}$, capturing the relative income of an individual state to that of the Indian national average; and, $Y_{3}$, capturing the relative income of the NER as a whole to that of the Indian national average (see following data section on how these variables are constructed). Testing for stochastic convergence of incomes per capita means that we test if our state series, $Y_{1 \mathrm{t}}$ or $Y_{2 \mathrm{t}}$, is stationarity or not. We proceed by testing if any of our series contain a unit root. If we can reject the unit root hypothesis for a given state "s", then we have sufficient evidence to conclude that state "s" stochastically converged towards the regional average, as in the case of $Y_{1 \mathrm{t}}$, or towards the Indian average, as in the case of $Y_{2}$. Similarly, rejecting a unit root null for the $Y_{3 t}$ series would unequivocally imply that the NER on average has stochastically converged to the Indian average in terms of per capita incomes over the period of study, suggesting a fall in regional income inequality for this region.
The main issue when it comes to testing for stochastic convergence is the question of which unit root tests to use. Perron's (1989) seminal work on unit root testing demonstrated that the omission of structural breaks can increase the likelihood of a false rejection of the unit root null hypothesis. To remedy this situation, Perron allowed for one known (or exogenous) structural break (intercept break, slope break or both-Model A, Model B or Model C, respectively, in Perron 1989) in the ADF unit root test. Despite the pioneering nature of his methodology, Perron's assumption of the known (exogenous) break date has been the subject of severe criticism in the literature, as the reliance on a known break date can lead to 'pre-testing' the data, which would be a form of 'data mining'. Since then, the subsequent literature addressed this problem of the known break date by adopting a completely agnostic approach, where a comprehensive and systematic search is done to endogenously determine the break date (see Perron 2005). The literature also complements this by allowing for more than one break in the testing procedure.

However, in spite of the similarity in the assumption of the endogenous break(s), there are methodological differences among some of these tests. In this paper, we use several unit root tests including the conventional Augmented Dicky-Fuller (ADF), Phillips-Perron (PP), Schmidt-Phillips (SP) and Kwiatkowski-Phillips-Schmidt-Shin (KPSS) tests. However, the test that we mainly rely upon is the Lagrange-Multiplier (LM) test proposed by Lee and Strazicich (2003, 2004, respectively, for the one and two breaks test). As emphasised in preceding sections, we hypothesise that since our data covers 35 years in total from 1980 to 2014, two breaks are satisfactory from a statistical point of view. Our a priori expectations, based on the reform period of the 1990s (including the initiation of LEP) and the implementation of LEP in the 2000s embodying PPMO and RPMO, would also suggest the presence of no more than two significant structural breaks. The advantage of this test is that the critical values are derived whilst assuming no break(s) under the null. Whilst other endogenous break(s) tests, such as those undertaken by Zivot and Andrews (1992) and Lumsdaine and Papell (1997), may conclude that a timeseries is trend-stationary, when in fact the series is non-stationary with break(s), the Lee and Strazicich tests avoid any potential 'spurious rejections' of the null. In contrast to other unit root tests which incorporate endogenously determined break date(s), the size properties of these test are unaffected by breaks under the null. As such, these tests are not subject to rejections of the null in the presence of a unit root with break(s). Thus, results using these LM tests are more revealing, since a rejection of the null in favour of trend-stationarity with one/two break(s) unambiguously implies stochastic convergence. The test implies that the shocks of the same percentage common to all states would leave relative 
real incomes per capita unchanged. Therefore, any structural break(s) identified would be state-specific. In terms of convergence, any identified structural break would imply a permanent change in a state's 'compensating differential'. from MoSPI and only needed to be divided by Indian population data to achieve per capita figures. ${ }^{9}$

Using the real income per capita data for the seven states as constructed above, relative real income per capita series were created, giving us the following three variables of interest. i.e.

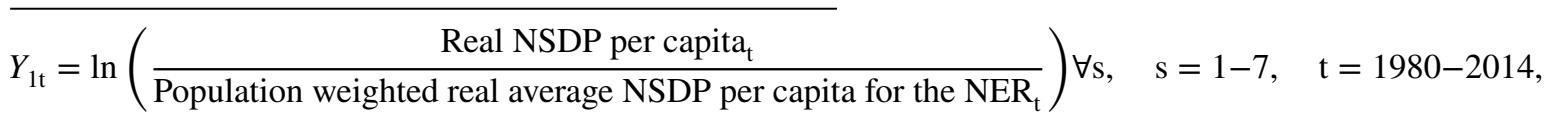

$Y_{2 \mathrm{t}}=\ln \left(\frac{\text { Real NSDP per capita }_{\mathrm{t}}}{\text { Real Indian average NSDP per capita }}\right) \forall \mathrm{t}, s=1-7, t=1980-2014$,

$Y_{3 \mathrm{t}}=\ln \left(\frac{\text { Population weighted real average NSDP per capita for the } \mathrm{NER}_{\mathrm{t}}}{\text { Real Indian average NSDP per capita } \mathrm{t}_{\mathrm{t}}}\right), t=1980-2014$,

\section{Data: Sources, Construction of Variables and Descriptive Statistics}

The data on net state domestic product (NSDP) in current and constant Indian rupees as well as population figures for the Seven Sister states were collected from the Ministry of Statistics and Programme Implementation (MoSPI), Government of India. Using these figures, with those in constant rupees being based on different base periods, we constructed our deflators through splicing the different series to generate a continuous deflator series with the base year of 2004-2005. A continuous series was then created for real NSDP in constant 2004-2005 rupees from 1980-1981 to 2014-2015 (referred to as 1980-2014 elsewhere in the paper for brevity), by deflating the respective nominal series based on current rupees by the constructed deflators. ${ }^{8}$ Real per capita figures were obtained by dividing the continuous series in 2004-2005 constant rupees by the population figures. This serves as our measure for real income per capita for the Seven Sisters. Meanwhile, the average Indian net domestic product in 2004-2005 constant rupees was readily available

\footnotetext{
8 The State Domestic Product (SDP) values in constant rupees for Mizoram were unavailable until 1999, therefore the Nagaland deflator was used for Mizoram for the period 1980-1998, as that series exhibited the strongest correlation with the Mizoram deflator series during 1999-2014.
}

where $Y_{1 t}$ is real NSDP per capita for each of the seven states relative to the seven-states population weighted average, $Y_{2 t}$ is real NSDP per capita for each of the seven states relative to the Indian average and $Y_{3 t}$ is the real seven states population weighted NSDP per capita relative to the Indian average, with all three series expressed in natural logarithms.

Descriptive statistics for real NSDP per capita for each of the seven states as well as for the seven states population weighted average and for the Indian average are presented in Table 2. During the period 1980 to 2014, only Nagaland demonstrated a mean value above that of the Indian average. This is in spite of the fact that three states showed a higher maximum NSDP per capita during this period when compared to the Indian average series (Mizoram, Nagaland and Tripura). An explanation for this lies in the strong growth of per capita incomes in these states during the latter part of the period under consideration, which is indicated by the higher positive skewness relative to the Indian average. Another salient observation emerging from the descriptive statistics is the number of states which have a mean value above the seven states population weighted average's mean (five out of the seven states). This can be attributed to the dominance

\footnotetext{
${ }_{9}$ It is to be noted that the net state domestic product (NSDP) used in this paper is net of indirect taxes. The corresponding gross state domestic product (GSDP) figures were also available from MoSPI and we have constructed continuous GSDP series as well. We have undertaken all tests of convergence for these GSDP data as reported for the series constructed using the NSDP data in the results section on this paper. The results and key findings are essentially unchanged, which therefore acts as a robustness check for our results. We do not report them for brevity, but these results are available from the authors upon request.
} 
Table 2 Descriptive statistics of NSDP per capita figures for the period 1980-1981 to 2014-2015

\begin{tabular}{|c|c|c|c|c|c|c|c|}
\hline NSDP per capita & Observations & Mean & Standard deviations & Minimum & Maximum & Skewness & Coefficient of variation \\
\hline Arunachal Pradesh & 35 & $19,188.82849$ & 9594.971511 & 7282.99953 & $37,683.26076$ & 0.655032246 & 1.999883843 \\
\hline Assam & 35 & $14,598.97252$ & 4289.373049 & 9461.295236 & $23,967.6814$ & 0.791402205 & 3.403521297 \\
\hline Manipur & 35 & $14,027.0661$ & 5394.757087 & 7998.815489 & $24,909.83394$ & 0.647099031 & 2.600129324 \\
\hline Meghalaya & 35 & $17,847.54908$ & 9462.605662 & 8365.095824 & $39,503.32339$ & 0.831936796 & 1.886113584 \\
\hline Mizoram & 35 & $20,426.82133$ & $10,482.40927$ & 8017.290144 & $43,161.78964$ & 0.832335461 & 1.948676187 \\
\hline Nagaland & 35 & $22,603.36894$ & $13,625.60995$ & 8325.076785 & $51,887.58685$ & 0.939789234 & 1.658888594 \\
\hline Tripura & 35 & $18,250.64725$ & $13,324.29861$ & 5563.050385 & $50,753.83026$ & 0.96555636 & 1.369726676 \\
\hline $\begin{array}{l}\text { Seven states popula- } \\
\text { tion Weighted } \\
\text { Average }\end{array}$ & 35 & $15,722.1513$ & 6148.528993 & 8903.801933 & $29,456.69734$ & 0.842821985 & 2.557058984 \\
\hline Indian average & 35 & $20,904.237$ & 9072.422285 & $10,712.21282$ & $40,632.81559$ & 0.842066562 & 2.304151674 \\
\hline
\end{tabular}

Source Authors' calculation based on figures from the Ministry of Statistics and Programme Implementation, Government of India

Table 3 Results of Augmented Dicky-Fuller (ADF), Phillips-Perron (PP), Schmidt-Phillips (SP) and Kwiatkowski-Phillips-Schmidt-Shin (KPSS) tests for $\ln (\mathrm{NSDPPC})$ relative to the Seven-State population weighted average

\begin{tabular}{|c|c|c|c|c|c|c|c|}
\hline \multirow{2}{*}{$\begin{array}{l}\ln (\text { NSDPPC) } \\
\text { State }\end{array}$} & \multicolumn{2}{|l|}{ ADF test } & \multicolumn{2}{|l|}{ PP test } & \multicolumn{2}{|l|}{ KPSS test } & \multirow{2}{*}{$\begin{array}{l}\text { SP test } \\
\text { SP test statistic }\end{array}$} \\
\hline & ADF test statistic & Lags & PP test statistic & Bandwidth & KPSS test statistic & Bandwidth & \\
\hline Arunachal Pradesh & -3.067064 & 4 & -2.05285 & 4 & 0.114763 & 4 & -2.118517 \\
\hline Assam & $-3.359912 *$ & 0 & $-3.361715^{*}$ & 1 & $0.161700^{* *}$ & 4 & -2.089148 \\
\hline Manipur & -2.768257 & 0 & -2.64759 & 5 & 0.079084 & 2 & -2.689235 \\
\hline Meghalaya & $-4.596505^{* * *}$ & 0 & $-4.606717 * * *$ & 2 & 0.098335 & 3 & -2.07591 \\
\hline Mizoram & $-3.599768^{* *}$ & 1 & -1.81678 & 11 & $0.124551^{*}$ & 3 & -2.412563 \\
\hline Nagaland & -2.403929 & 0 & -2.40393 & 0 & 0.088938 & 4 & -2.44021 \\
\hline Tripura & $-3.904149 * *$ & 0 & $-3.904149 * *$ & 0 & 0.098645 & 4 & -1.608344 \\
\hline
\end{tabular}

Source: Authors' estimations

For the ADF test lags selected using Akaike Information Criterion

For the PP and KPSS test the Newey-West automatic bandwidth selected using Bartlett Kernel

All the tests include a trend and intercept

For all the tests the null hypothesis is that the series contains a unit root, except for KPSS, where the null is that the series has no unit root

$* * * 1 \%$ significance, $* * 5 \%$ significance, $* 10 \%$ significance

of relatively poor Assam when calculating the population weighted average, as in any given year it contains at least $67 \%$ of the total population of the Seven Sisters; however, this figure has steadily fell throughout the period, starting from $72 \%$ in 1980 .

\section{Results and Discussion}

\section{Stochastic Convergence Tests Results and Key Findings}

As previously stated, three different sets of variables are used, the natural log of income per capita for each state relative to the seven states population weighted average income per capita $\left(\mathrm{Y}_{1 \mathrm{t}}\right)$ and relative to the Indian average income per capita $\left(\mathrm{Y}_{2 \mathrm{t}}\right)$, as well as the natural log of the seven states population weighted average income per capita relative to the Indian average income per capita $\left(Y_{3 t}\right)$. Evidence for the presence of a unit root in a series would suggest that state or regional incomes per capita are diverging; whilst the absence of a unit root would signal that incomes per capita are stochastically converging towards their individual steady-states, suggesting the effectiveness of the LEP in terms of its development agenda for the NER.

The results of the conventional unit root tests, which do not account for any breaks in the data, are presented in Table 3 as the benchmark. These are the Augmented Dicky-Fuller (ADF), Phillips-Perron (PP), Schmidt-Phillips (SP) and Kwiatkowski-Phillips-Schmidt-Shin (KPSS) tests. When looking at the results of the log of net state domestic product per capita figures relative to the seven 
Table 4 Results of Augmented Dicky-Fuller (ADF), Phillips-Perron (PP), Schmidt-Phillips (SP) and Kwiatkowski-Phillips-Schmidt-Shin (KPSS) tests for $\ln (\mathrm{NSDPPC})$ relative to the Indian average

\begin{tabular}{|c|c|c|c|c|c|c|c|}
\hline \multirow{2}{*}{$\begin{array}{l}\ln (\text { NSDPPC) } \\
\text { State }\end{array}$} & \multicolumn{2}{|l|}{ ADF test } & \multicolumn{2}{|l|}{ PP test } & \multicolumn{2}{|l|}{ KPSS test } & \multirow{2}{*}{$\begin{array}{l}\text { SP test } \\
\text { SP test statistic }\end{array}$} \\
\hline & ADF test statistic & Lags & PP test statistic & Bandwidth & KPSS test statistic & Bandwidth & \\
\hline Arunachal Pradesh & -2.661327 & 0 & -2.66948 & 1 & 0.084375 & 4 & -2.640443 \\
\hline Assam & -3.085552 & 0 & -3.08555 & 0 & 0.071111 & 2 & -2.707008 \\
\hline Manipur & -3.000935 & 0 & -3.05196 & 2 & 0.080964 & 3 & $-3.013026^{*}$ \\
\hline Meghalaya & $-3.687898 * *$ & 0 & $-3.603134 * *$ & 3 & $0.124760 *$ & 3 & -2.640878 \\
\hline Mizoram & $-4.13877 * *$ & 2 & -3.1687 & 33 & 0.086183 & 3 & $-3.062182 *$ \\
\hline Nagaland & -2.515216 & 0 & -2.51522 & 0 & $0.119935^{*}$ & 4 & -2.534223 \\
\hline Tripura & $-3.32167 *$ & 0 & $-3.32167 *$ & 0 & 0.108496 & 4 & -1.774905 \\
\hline $\begin{array}{l}\text { Seven-state Population } \\
\text { Weighted Average }\end{array}$ & -2.720182 & 0 & -2.70595 & 1 & $0.119506^{*}$ & 3 & -2.740361 \\
\hline
\end{tabular}

Source Authors estimations

For the ADF test lags selected using Akaike Information Criterion

For the PP and KPSS test the Newey-West automatic bandwidth selected using Bartlett Kernel

All the tests include a trend and intercept

For all the tests the null hypothesis is that the series contains a unit root, except for KPSS, where the null is that the series has no unit root

$* * * 1 \%$ significance, $* * 5 \%$ significance, $* 10 \%$ significance

states' population weighted average, the null hypothesis of a unit root can be rejected for four states when using the ADF test (Assam, Meghalaya, Mizoram and Tripura), for three states using the PP test (Assam, Meghalaya and Tripura) and for no states based on the results of SP test. In the case of the KPSS test, where the null is formulated such that its rejection indicates the presence of a unit root, we find that we can reject the null of stationarity in the cases of two states (Assam and Mizoram).

Table 4 presents the results of the conventional unit root tests when our variables of interest are the natural $\log$ of state incomes per capita relative to the Indian average, as well as the natural log of the seven states' population weighted average income per capita relative to the Indian average. We find that the null of a unit root can be rejected for three states based on the ADF test (Meghalaya, Mizoram and Tripura), for two states based on the PP test (Meghalaya and Tripura), and for two states based on the SP test (Manipur and Mizoram). Meanwhile only two states, Meghalaya and Nagaland, rejects the null of stationarity with the KPSS test. When examining the natural log of the seven states' population weighted average income per capita relative to the Indian average, it is apparent that all the four tests provide evidence of divergence of the region's income per capita from that of the national average. Based on the results of the preceding tests, we find evidence of stochastic divergence of incomes with some moderate evidence of income convergence for specific tests.

We now turn to the results from the unit root tests with break(s). Since our relative income series spans 35 years in total, a period which includes both a phase of wide-reaching economic reforms in the 1990 s, including the initiation and formulation of the LEP and more systematic (albeit gradual and incremental) implementation of the development agenda of the LEP for the benefit of the NER in the 2000s, therefore the presence of structural breaks is to be expected. If we were to ignore such structural breaks in our data, then we could erroneously conclude in favour of stochastic divergence of per capita incomes, as suggested by our previous results. Our preferred tests are the ones developed by Lee and Strazicich (2003, 2004, hereafter LS2 and LS1, respectively), which endogenously determine one (in the LS1 test) and two (in the LS2 test) structural break(s) in intercept and slope. In contrast to earlier tests, the size properties of the LS1 and LS2 tests are unaffected by breaks under the null, which means that these tests are not subject to rejections of the null in the presence of a unit root with break(s). Consequently, the rejection of the null in favour of trend-stationarity with one/two break(s) unambiguously implies stochastic convergence (see Chapters 4 and 5 in Choudhury 2012).

The LS2 test was carried out first for all the variables because of the two distinct phases of policy changes, the 1990s and 2000s. Due to the relatively short time period of 35 years, we would not expect more than two breaks. ${ }^{10}$ Results from the LS2 tests are presented in Table 5. We find that every state rejects the null of a unit root when using per capita income figures relative to the seven states population weighted average income per capita suggesting the

\footnotetext{
${ }^{10}$ We only undertook the LS1 test when one of the break dates iden-
} tified by the LS2 test was statistically insignificant. 
Table 5 Results from the Lee and Strazicich 2-break and 1-break test

\begin{tabular}{|c|c|c|c|c|c|c|c|}
\hline \multirow[t]{2}{*}{ State } & \multicolumn{4}{|l|}{ LS2 test } & \multicolumn{3}{|l|}{ LS1 test } \\
\hline & LS2 test statistic & Lags & Break 1 & Break 2 & LS1 test statistic & Lags & Break \\
\hline \multicolumn{8}{|c|}{$\ln (\mathrm{NSDPPC})$ relative to seven-state population weighted average } \\
\hline Arunachal Pradesh & $-9.082 * * *$ & 8 & $1995 n$ & 2002 & -4.1759 & 7 & $2006 n$ \\
\hline Assam & $-5.5556^{*}$ & 8 & 1994 & 2002 & & & \\
\hline Manipur & $-6.2148 * *$ & 8 & 1991 & 2007 & & & \\
\hline Meghalaya & $-5.8031 * *$ & 7 & 1993 & 2005 & & & \\
\hline Mizoram & $-6.6459 * * *$ & 6 & 1991 & 2007 & & & \\
\hline Nagaland & $-9.4951 * * *$ & 8 & 1997 & 2002 & & & \\
\hline Tripura & $-6.2259 * *$ & 6 & 1991 & 2005 & & & \\
\hline \multicolumn{8}{|c|}{$\ln (\mathrm{NSDPPC})$ relative to the Indian average } \\
\hline Arunachal Pradesh & $-6.571 * * *$ & 2 & 1995 & 2003 & & & \\
\hline Assam & $-5.7126 * *$ & 6 & 1993 & 1999 & & & \\
\hline Manipur & $-5.4831 *$ & 2 & 1997 & 2009 & & & \\
\hline Meghalaya & $-6.0256^{* *}$ & 8 & 1991 & 2007 & & & \\
\hline Mizoram & $-7.7557 * * *$ & 6 & 1993 & 1999 & & & \\
\hline Nagaland & $-10.21 * * *$ & 8 & $1997 \mathrm{n}$ & 2002 & $-4.9967 * *$ & 4 & 2002 \\
\hline Tripura & $-9.9711 * * *$ & 8 & 1992 & 2002 & & & \\
\hline $\begin{array}{l}\text { Seven-state popula- } \\
\text { tion weighted } \\
\text { average }\end{array}$ & $-8.1409 * * *$ & 6 & 1993 & 1999 & & & \\
\hline
\end{tabular}

Source Authors estimations

Lags selected with the general to specific approach from a maximum of 8. Critical value for a two-tailed test with $30 \mathrm{df}$ is 1.697 , and $\mathrm{n}$ denotes a non-significant break. Null hypothesis of unit root

We only undertook the LS1 test when one of the breaks from the LS2 test was insignificant

$* * * 1 \%$ significance, $* * 5 \%$ significance, $* 10 \%$ significance stochastic convergence of incomes for each state to the NER as a whole. Additionally, the unit root null is rejected for all states when using per capita income figures relative to the national average income per capita providing evidence on stochastic convergence of state incomes to the Indian average. We also find that the two break dates were statistically significant at $10 \%$ or better levels of significance in all but two cases. The two series where one of the breaks was insignificant are the natural log of NSDP per capita relative to the seven states population weighted average for Arunachal Pradesh, and the natural log of NSDP per capita relative to the Indian average for Nagaland. For these series, we additionally carry out the LS1 test, also shown in Table 5, and we find that the Arunachal Pradesh series no longer rejects the unit root null, and the break date is insignificant, whilst the Nagaland series still rejects the null and the sole break date is significant. When we turn our attention to the natural log of the seven states population weighted average per capita income relative to the Indian average, we find that the null is rejected by the LS2 test, with both the break dates being statistically significant.

Our results provide firm evidence in favour of the hypothesis that stochastic convergence of incomes per capita has occurred within the Seven Sisters, and in relation to the rest of India, between 1980 and 2014. Based on the seven-state series, the unit root null for the log of relative real income per capita to the population weighted average income per capita is rejected in each case by using the two-break LM unit root tests. We also reject the unit root null when considering the log of relative real income per capita to the Indian average income for all seven states. Additionally, we find that the series comprising the natural log of the seven states population weighted average income per capita relative to the Indian average income per capita, also rejects the unit root null when we apply the two-break LM unit root test, thus implying that the region as a whole is converging to the national average in terms of incomes per capita.

Our analysis presents strong evidence that the real income per capita across Seven Sisters have stochastically converged to their own 'compensating differentials' between 1980 and 2014. The conditional convergence of inter-state income per capita across Seven Sisters vis-à-vis the 'compensating differentials' suggests that market-oriented policies and associated development initiatives proved effective in reducing regional inequality. The fact that these states also conditionally converged to their 'compensating differentials', with respect to the Indian average, imply that the macro reforms of the 1990s and the directed development 
policies post 1991, albeit implemented haphazardly, resulted in economic recovery. The ethical dimension inherent in the implementation of the LEP generated economic momentum for the NER as a whole, which in turn stochastically converged towards the rest of India in terms of income per capita. Significantly, the presence of statistically significant structural breaks identified by our testing procedure indicates that during the period under consideration, two shifts took place which permanently affected most states' and the region's 'compensating differentials'. A possible explanation for this is that the significant economic reforms and directed regional development policy taking place at the time altered the relative levels of investment and technology in the affected states. We attribute the first break to the macro and structural reforms (trade liberalisation, industrial reforms and delicensing as part of the pro-market reforms) implemented in the 1990s, and the second break as a consequence of the LEP's domestic market-oriented policies tailored to enhance the connectivity of the local economy with regional, national and international markets. Obviously, the impact of policy on relative income series for each state differs because of heterogeneous individual dynamics, resulting in leads and lags in the break dates. The fact that each series has two statistically significant breaks (with the exception of Arunachal Pradesh relative to the NER average and Nagaland relative to Indian average) corroborates the above explanation.

The implication of our findings in terms of the ethical dimension of the PMO is that the government of India, despite regime changes ${ }^{11}$, was able to make progress in its developmental goals for the NER as envisioned in the LEP through gradual and incremental engagement with one of the key stakeholders (e.g. state governments). The overwhelming evidence of income convergence of the Seven Sisters with each other, as well as of the region with the national average, suggests that the LEP achieved its stated internal aim of elevating the economy of the NER and its growth trajectory, to bring it up to par with the rest of the country. There was an active attempt by the government of India to engage with stakeholders, including state governments, the NEC and the local populace. It was also able

\footnotetext{
11 The LEP was developed and enacted during the Congress-led government of Prime Minister (PM) P.V. Narsimha Rao (1991-1996) and rigorously pursued by coalition-led United Front PM H. D. Deve Gowda (1996-1997) followed by I.K. Gujral (1997-1998). The Bhartiya Janta Party (BJP)-led government under Atal Bihari Vajpayee (1998-2004) and the successive Congress-led governments of PM Manmohan Singh (1998-2004) and (2004-2014) continued with economic liberalisation along with focusing on forging close economic and commercial ties, increasing strategic and security cooperation with neighbours.
}

to engage with macro-level stakeholders like foreign governments, especially in the form of economic cooperation with Myanmar and political cooperation with Bangladesh, facilitating the creation of commercial links between the north-eastern states and these Southeast Asian countries, which has also greatly benefitted the income generation capacity of the NER states. There is evidence that whilst the share of agriculture and allied activities has declined, the industrial and services sectors have both increased in all seven states between 2010-2011 and 2013-2014 (Salve and Pandit 2016).

\section{Limitations and Further Research}

Our findings lend support to our earlier contention that the ethical dimension in PMO has the power to curtail unethical practices and behaviour. In fact, the GOI, via means of the LEP, did attempt to reverse the 'neglect' the NER had faced due to ill-conceived policies, albeit in an unfocussed and haphazard way. As such, at the macro-level, we find evidence for per capita income convergence, which implies that the standard of living is improving on average. However, microlevel aspects such as the LEP's impact in ameliorating the rural-urban disparities can only be understood in sufficient depth with additional, longitudinal/ethnographic qualitative research focusing on both managers and consumers of policy outcomes. Dholakia (2012) observes that in India, fields like marketing and management suffer from the lack of a critical perspective as the tendency is towards the "... silencing of local subaltern stakeholders" (Varman and Saha 2009, p. 811, cited in Dholakia). Thus, we identify this gap as a significant area for future studies to address: to map accurately the microlevel impact of the LEP, and how these lessons can inform the Indian Government's Act East Policy, launched in 2014 at the India-ASEAN Summit in Myanmar, to replace the LEP.

Further, the application of marketing tenets to the political domain is not without limitations. For instance, the underlying exchange interactions in the political context are often non-reciprocal and involve public goods, plus demonstrate a far more complex morphology in comparison with commercial exchanges (Henneberg 2002). Whilst the nature of political offering is essentially intangible or promise-based (Scammell 1999), political marketing activities can take an ugly turn, due to an emphasis on negative campaigns designed to belittle other parties' achievements (O'Shaughnessy 2002). Whilst these differences do not render the use of marketing concepts in a political context extraneous, they do necessitate a careful adaptation.

Additionally, the empirical findings in this paper provide statistical evidence of income convergence for the states in India's NER to the region as a whole and to the national average implying falling regional income disparity. We attempt to correlate this result to policy changes in the 1990s 
Fig. 3 Structural breaks and policy regimes. Source Authors' construction
Relative Income Per Capita Series: Structural Breaks and Three Policy Regimes

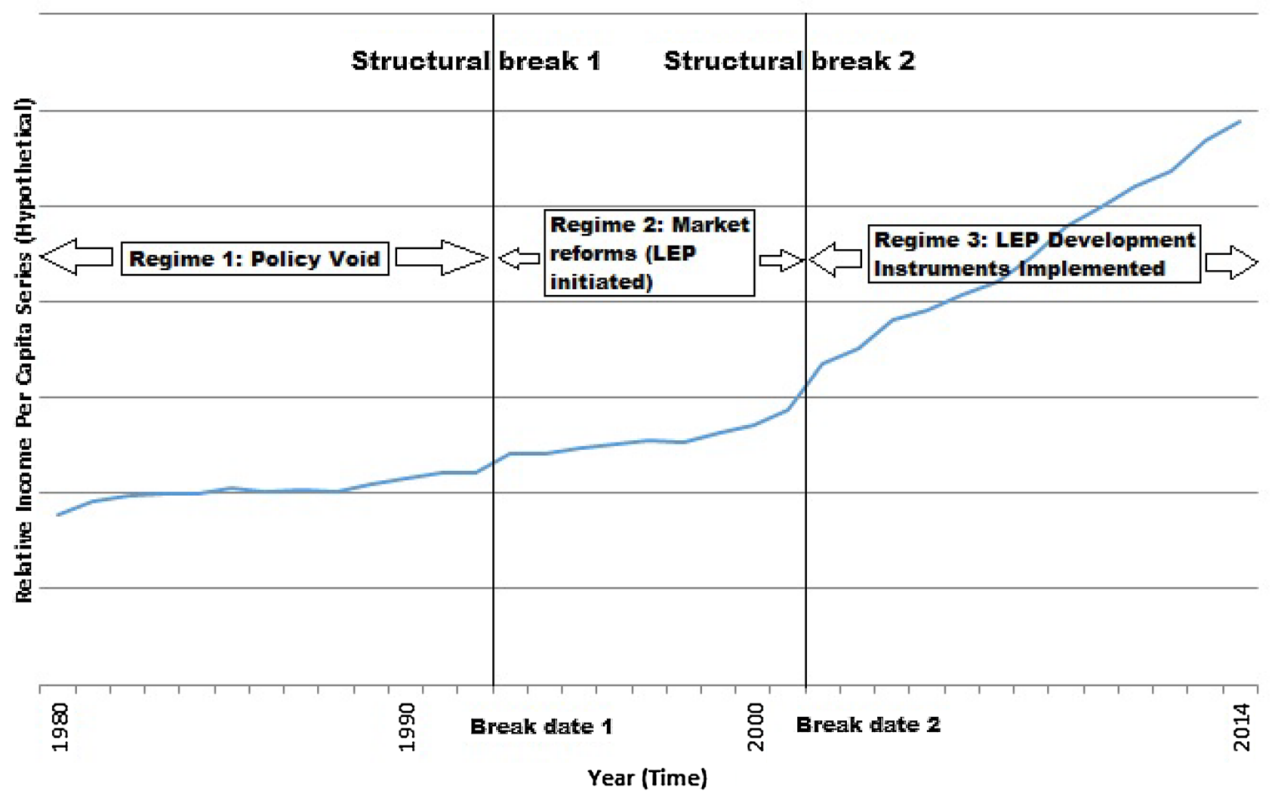

and 2000s, and conclude that the presence of two structural breaks-one in the 1990s and one in the 2000s for most states-provide evidence to our hypothesis that the reforms and initiation of LEP in the 1990s and the implementation of development instruments of LEP in the 2000s, embodying PPMO and RPMO, respectively, have resulted in improved economic performance of the Seven Sister states and the NER as a whole. In this sense, our income growth empirics identify three policy regimes for each state and for the NER as a whole. The first regime between 1980 and the first structural break date capture relative income dynamics during a period that was characterised by a policy void. The second regime between the first and second break dates coincides with a period that saw unprecedented market-oriented reforms throughout India (1990s) and the initiation of the LEP. The third regime between the second break date and 2014 coincides with a period that saw intensified implementation of the development instruments of the LEP in the 2000s (see Fig. 3 for a visual exposition with a hypothetical relative income per capita series).

Our attempt is therefore limited to using the ethical dimension in the PMO framework to understand the regional impact and domestic dimension of the LEP on the NorthEastern states of India, through testing for regional income convergence and identifying three distinct policy regimes (by identifying two state-specific structural breaks endogenously) that account for the observed growth patterns of relative incomes per capita. Whilst we examine how policy changes can potentially balance (or polarise) cross-regional growth, we do recognise that there is more to simply analysing regional income convergence. However, our paper does not identify the nexus of causal channels through which reforms and specific policy changes affect the overall regional income distribution. Such a task is not impossible, but it is definitely complicated and will require both a quantification of the development instruments of the LEP and a micro-level household and/or firm-level survey data to fully capture the LEP's impact on the NER's communities and businesses, an area that we intend to explore in our future work. It may be argued that the annual data that we use in this paper are low frequency, and to that extent, it can be construed as a limitation of the paper. However, we have 35 annual observations for each time-series spanning over three and half decades of policy changes, which is considered rich both from a developing country perspective as well from a statistical estimation perspective. ${ }^{12}$ Overall, our main focus in this paper has been to identify potential correlates, using a unified analytical framework that combines the theoretical context informed by the ethical dimension in the PMO with the empirical approach embedded in work on income convergence from the regional economics literature. Together, they allow us to offer distinctive insights into the impact of

\footnotetext{
12 Our use of annual data for the kind of time-series analysis that we have undertaken, identifying structural breaks endogenously from the data and attributing them to different policy regimes, is in line with other published work in the context of India-see, for instance, Chatterji and Choudhury (2013), among others. Chatterji and Choudhury (2013) used 31 annual observations to identify two structural breaks in their examination of the inter-industry wage structure in India in the context of gradual and incremental reforms.
} 
the LEP on regional convergence of incomes in the NER and analyse the observed regional income growth patterns.

\section{Conclusions}

In sum, we reiterate that the dynamics of income convergence in the NER underline the positive outcomes of the LEP. Our analysis points out clearly that the seven states in the NER have converged to the rest of India both individually and as a region since 1980 in terms of incomes per capita. Using stationarity tests that allow to account for structural breaks in time-series data on income per capita for 35 years, we conclude that stochastic convergence of incomes per capita across the seven NER states as well as the region as a whole to that of the national average has taken place. It can be argued that at the macro-level, there is a shift towards an equitable regional income distribution in the NER, thus suggesting fall in regional inequality. This assessment was undertaken against the backdrop of decades of targeted regional economic policy, marketed by the GOI as part of its flagship LEP and more recently Act East policy (AEP), both of which support the NER's capacity to serve as India's gateway to the Southeast Asia region. The evidence lends support to the conjecture that despite its limitations, the LEP was able to positively impact on the socio-economic policy-making processes and contributed to income convergence in the Seven Sisters.

A key statistical contribution of our work is that we let the data speak and endogenously determine two structural breaks from long time-series data, rather than specifying an exogenous break based on historic and theoretical conjectures. Thus, through our conceptual framework that links the PMO with time-series evidence, we illustrate how macro reforms and the initiation of the LEP in the 1990s, together with the intensified implementation of the development agenda of the LEP in the 2000s, have brought about income convergence in the NER. Reform processes are incremental and gradual in nature and have heterogeneous effects on states, as our findings demonstrate via the identification of two state-specific structural breaks, which coincide with the two distinct policy regimes of the 1990s and 2000s.

Broadly, this study contributes to the emerging literature on the PMO within the political marketing domain, focusing on how the dynamism of market-oriented policies derives from complex interface between different stakeholders (Lees-Marshment 2001; Ormrod 2007). By focusing on the ethical dimension in PMO (and two related sub-constructs of PPMO and RPMO), we argue that it can be a source of competitive advantage, as by linking with the complex needs of different stakeholders, market-oriented policies like the
LEP can bring about lasting change. There has been little attention paid to the interplay between heterogeneous stakeholders tackling market-oriented economic reforms at different institutional levels in the NER. Hence, empirically this study is one of the first to examine how the LEP and concurrent economic change occurred through the interplay of (i) the shared vision and values of macro-level stakeholders; (ii) meso-level bodies (e.g. those operating at the State and District levels) that interpreted and implemented reformoriented policies; and (iii) the adoption of new practices, expectations and behaviours at the micro-level. It is clear that the LEP acted as a shock to the existing economic system, as is evident from the presence of statistically significant structural breaks identified by our testing procedure, indicating that during the period under consideration, two state-specific shifts to relative incomes per capita took place, which permanently affected most states' and the region's 'compensating differentials'.

Das (2010) suggests that whilst India's Northeast, South Asia and South-East Asia might have remained politically separate, in the light of changing economic realities, they have the potential to coalesce into a composite region of 'Northeast India, South and South East Asia' (NISASEA) along the lines of the European Union. Indeed, a number of recent developments in the NER indicate how it is being rebranded in this manner, to enable it to contribute to the restoration of greater integration in the region (Bhattacharjee 2016). Our findings indicate clearly that regional inequality reduced both within the NER, as well as between the NER and the national average between 1980 and 2014, aided by the launch of fundamental economic reforms that spanned the full length of the LEP and directed regional development policy as part of the broader LEP. The current government seeks to develop the NER through greater economic integration with Southeast Asia via a Natural Economic Zone. Given the contiguous landscape and common lifestyles that people across overlapping borders share, this does not seem far-fetched. However, for the region to emerge as a strategic stakeholder in sustaining the dynamism and processes of the free market, the AEP will need to consciously work at being inclusive. Hitherto, the framework of reform has been conceived from the statist perspective, which widens the gap between different stakeholders (Ziipao 2018).

In closing, we underline that the significance of our study lies in its illustration of how commercial marketing vocabulary can contribute to an analytical understanding of increasingly market-driven and yet surprisingly ethical policy-making processes. Indeed, empirical evidence emerging from stochastic convergence of incomes per capita for the Seven Sister states of the NER in India well illustrates how regional economic inequality can be reduced through targeted market-oriented policies. 
Acknowledgements The authors are grateful to the editors, Dr Haseeb Shabbir and Dr Michael R. Hyman, plus three anonymous reviewers for their insightful comments and suggestions.

\section{Compliance with Ethical Standards}

Conflict of interest The authors declare that they have no conflict of interest.

Ethical Approval This article does not contain any studies with human participants or animals performed by any of the authors.

Open Access This article is distributed under the terms of the Creative Commons Attribution 4.0 International License (http://creativeco mmons.org/licenses/by/4.0/), which permits unrestricted use, distribution, and reproduction in any medium, provided you give appropriate credit to the original author(s) and the source, provide a link to the Creative Commons license, and indicate if changes were made.

\section{References}

Atuahene-Gima, K., Slater, S. F., \& Olson, E. M. (2005). The contingent value of responsive and proactive market orientations for product innovation. Journal of Product Innovation Management, 22(6), 464-482.

Banks, S. (1999). The social professions and social policy: Proactive or reactive? European Journal of Social Work, 2(3), 327-339.

Barney, J. (1991). Firm resources and sustained competitive advantage. Journal of Management, 17(1), 99-120.

Barro, R. J. (1991). Economic growth in a cross section of countries. The Quarterly Journal of Economics, 106(2), 407-443.

Barro, R. J., \& Sala-i-Martin, X. (1997). Technological diffusion, convergence, and growth. Journal of Economic Growth, 2(1), 1-26.

Bathelt, H., \& Glückler, J. (2003). Toward a relational economic geography. Journal of Economic Geography, 3(2), 117-144.

Bathelt, H., \& Glückler, J. (2011). The relational economy: Geographies of knowing and learning. Oxford: Oxford University Press.

Baumol, W. (1986). Productivity growth, convergence and welfare. American Economic Review, 76(5), 1072-1085.

Bhattacharjee, D. (2016). India's Vision on Act East Policy. Event Paper presented at the National Seminar on India's Act East Policy: Problems and Prospects in North East India Delhi: Indian Council of World Affairs, 28-29 January. Retrieved 04 May, 2018, from https://icwa.in/pdfs/ssreports/2014/eventreportpapermani pur29jan2016.pdf.

Bhattacharya, R. (2014). Development-gaps and security-sensitivity: Revisiting some links in India's Northeast. Man and Society, X1, 62-80.

Bhattacharya, C. B., \& Korschun, D. (2008). Stakeholder marketing: Beyond the four Ps and the customer. Journal of Public Policy and Marketing, 27(1), 113-116.

Bhaumik, S. (2014). Look East through Northeast: Challenges and prospects for India. New Delhi: Occasional Papers, Observer Research Foundation.

Capoccia, G., \& Kelemen, R. D. (2007). The study of critical junctures: Theory, narrative, and counterfactuals in historical institutionalism. World Politics, 59(3), 341-369.

Carlino, G. A., \& Mills, L. O. (1993). Are US regional incomes converging? Journal of Monetary Economics, 32(2), 335-346.
Chatterjee, S. (2007). Conceptions of space in India's look east policy: Order, cooperation or community? South Asian Survey, 14(1), 65-81.

Chatterjee, S. (2014). The Look East Policy and the Northeastern States. Singapore: S. Rajaratnam School of International Studies.

Chatterji, M., \& Choudhury, H. (2013). Liberalisation and the changing inter-industry wage structure of the organised manufacturing sector in India, 1973-1974 to 2003-2004. Review of Development Economics, 17(2), 365-378.

Choudhury, H. (2010). Trade reforms and performance in Indian manufacturing. Saarbrucken: Lambert Academic Publishing.

Choudhury, H. (2012). Essays on the Changing Inter-Industry Wage Structure in India. Unpublished PhD Thesis, Economic Studies, University of Dundee.

Choudhury, H., \& Hawes, M. (2014). Are Incomes Per Capita Stochastically Converging Between Indian States? Time Series Evidence with Two Structural Breaks, Annual Shanghai Business, Economics and Finance Conference, Shanghai, China, 03/11/2014-04/11/2014.

Christiano, L. J. (1992). Searching for a break in GNP. Journal of Business and Economic Statistics, 10(3), 237-250.

Coleman, S. (2007). Review of Lilleker and Lees-Marshment (2005). Parliamentary Affairs, 60(1), 180-186.

Commission, Planning. (2013). Annual Report 2012-2013. New Delhi: Planning Commission, Government of India.

Dabla-Norris, E. \& Wade, P. (2001). Rent-seeking and endogenous income inequality. IMF Working Paper No. WP/01/15, International Monetary Fund, Washington D.C.

Das, S. K. (2010). India's look east policy: Imagining a new geography of India's Northeast. India Quarterly, 66(4), 343-358.

Deardorff, A. V. (2014). Terms of trade-Glossary of International Economics (2nd ed.). Singapore: World Scientific.

Dholakia, N. (2012). Being critical in marketing studies: The imperative of Macro perspectives. Journal of Macromarketing, 32(2), 220-225.

Dickey, D. A., \& Fuller, W. A. (1979). Distribution of the estimators for autoregressive time series with a unit root. Journal of the American Statistical Association, 74(366), 427-431.

Freeman, R. E., Harrison, J., \& Wicks, A. (2007). Managing for stakeholders: Survival, reputation, and success. New Haven: Yale University Press.

Freeman, R. E., Wicks, A. C., \& Parmar, B. (2004). Stakeholder theory and "the corporate objective revisited". Organization Science, 15(3), 364-369.

Fritzsche, D. J. (1991). A model of decision-malting incorporating ethical values. Journal of Business Ethics, 10(11), 841-852.

Goldberg, J. (2017). India's Look East Policy: India Looks East to Strengthen Economic and Strategic Relations. March 17. Retrieved 29 March, 2019, from https://www.thoughtco.com/ look-east-policy-of-india-1435050.

Haokip, T. (2011). India's look east policy: Its evolution and approach South Asian Survey, 18(2), 239-257.

Harvey, A. C. (1997). Trends, cycles and autoregression. The Economic Journal, 107(440), 192-201.

Henneberg, S. C. (2002). Understanding political marketing. In N. J. O'Shaughnessy \& S. C. Henneberg (Eds.), The idea of political marketing (pp. 93-170). Westport: Praegor.

Henneberg, S. C. (2006). Leading or following? A theoretical analysis of political marketing postures. Journal of Political Marketing, $5(3), 29-46$

Hoeffler, S., \& Keller, K. L. (2002). Building brand equity through corporate social marketing. Journal of Public Policy and Marketing, 21(1), 78-89.

ICWA (2015). "Report on the Seminar-Integrating Northeast in India's Act East Policy", Indian Council of World Affairs. 
Retrieved 23 February, 2015, from http://www.icwa.in/pdfs/crepo rts/2014/seminarreport23022015.pdf.

Jaffrelot, C. (2003). India's look east policy: An Asianist strategy in perspective. India Review, 2(2), 35-68.

Jaworski, B., \& Kohli, A. K. (1993). Market orientation: Antecedents and consequences. Journal of Marketing, 57(3), 53-70.

Kathuria, S. (2017). Bangladesh Corridor Vital to India's 'Act East' Policy. Hindustan Times, 26th September, New Delhi.

Kingdon, J. W. (1964). Agendas, alternatives, and public policies. London: Longman.

Kirca, A., Jayachandran, S., \& Bearden, W. (2005). Market orientation, A meta-analytic review and assessment of its antecedents and impact on performance. Journal of Marketing, 69(2), 24-41.

Kohli, A. K., \& Jaworski, B. J. (1990). Market orientation: The construct, research propositions, and managerial implications. Journal of Marketing, 54(2), 1-18.

Kohli, A. K., Jaworski, B. J., \& Kumar, A. (1993). MARKOR: A measure of market orientation. Journal of Marketing Research, 30(4), 467-477.

Krueger, A. O. (1974). The Political Economy of the Rent Seeking Society. American Economic Review, 64(3), 291-303.

Kwiatkowski, D., Phillips, P. C. B., Schmidt, P., \& Shin, Y. (1992). Testing the null hypothesis of stationarity against the alternative of a unit root: How sure are we that economic time series have a unit root? Journal of Econometrics, 54(1), 159-178.

Lee, J., \& Strazicich, M. C. (2003). Minimum Lagrange multiplier unit root test with two structural breaks. Review of Economics and Statistics, 85(4), 1082-1089.

Lee, J. \& Strazicich, M.C. (2004). Minimum LM Unit Root Test with One Structural Break. Working Paper, Department of Economics, Appalachian State University.

Lees-Marshment, J. (2001). The marriage of politics and marketing. Political Studies, 49(4), 692-713.

Levitt, T. (1960). Marketing Myopia. Harvard Business Review, 38(4), $45-56$.

Lindblom, C. (1980). The policy making process. Englewood Cliffs: Prentice-Hall.

Lumsdaine, R. L., \& Papell, D. H. (1997). Multiple trend breaks and the unit-root hypothesis. Review of Economics and Statistics, $79(2), 212-218$.

Maignan, I., Hult, T. \& Ferrell, O.C. (2007). Stakeholder and market orientations: Which drives outcomes in a more significant way? Working paper, Michigan State University, East Lansing.

Mitchell, R. K., Agle, B. R., \& Wood, D. J. (1997). Toward a theory of stakeholder identification and salience: Defining the principle of who and what really counts. Academy of Management Review, 22(4), 853-886.

Morgan, R., \& Strong, C. (1998). Market orientation and dimensions of strategic orientation. European Journal of Marketing, 32(11-12), 1051-1073.

Naidu, G. V. C. (2001). India and the Asia-Pacific Balance of Power. Strategic Analysis, 25(4), 503-518.

Naidu, G. V. C. (2004). Whither the look east policy: India and Southeast Asia. Strategic Analysis, 28(2), 331-346.

Narver, J., \& Slater, S. F. (1990). The effect of a market orientation on business profitability. Journal of Marketing, 54(4), 20-35.

Nunes, L. C., Newbold, P., \& Kuan, C. (1997). Testing for unit roots with breaks: Evidence on the great crash and the unit root hypothesis reconsidered. Oxford Bulletin of Economics and Statistics, 59(4), 435-448.

O'Shaughnessy, N. J. (2002). Toward an ethical framework for political marketing. Psychology and Marketing, 19(12), 1079-1095.

O'Cass, A., \& Voola, R. (2011). Explications of political market orientation and political brand orientation using the resource-based view of the political party. Journal of Marketing Management, 27(5-6), 627-645.

Ormrod, R. P. (2005). A conceptual model of political market orientation. Journal of Nonprofit \& Public Sector Marketing, 14(1-2), 47-64.

Ormrod, R. P. (2006). A critique of the Lees-Marshment market-oriented party model. Politics, 26(2), 110-118.

Ormrod, R. P. (2007). Political market orientation and its commercial cousin: Close family or distant relatives? Journal of Political Marketing, 6(2-3), 69-90.

Ormrod, R. P. (2014). Political Market Orientation and the Network Party Type: Understanding Relationship Structures in Political Parties. Management Working Papers 2014-03, Institute for Economics and Management, Aarhus University.

Ormrod, R. P., \& Henneberg, S. C. (2009). An investigation into the relationship between political activity levels and political market orientation. European Journal of Marketing, 44(3-4), 382-400.

Ormrod, R. P., \& Savigny, H. (2011). Political market orientation A framework for understanding relationship structures in political parties. Party Politics, 18(4), 487-502.

Pandey, V., \& Gupta, S. (2016). Understanding G2G e-government project impasse: A stakeholder theory perspective. Information Development, 33(4), 361-374.

Perron, P. (1989). The great crash, the oil price shock and the unit root hypothesis. Econometrica, 57(6), 1361-1401.

Perron, P. (2005). Dealing with Structural Breaks. Working Papers Series No. WP2005-017, Department of Economics, Boston University.

Phillips, P. C. B., \& Perron, P. (1988). Testing for a unit root in time series regression. Biometrika, 75(2), 335-346.

Quah, D. T. (1993). Galton's Fallacy and tests of the convergence hypothesis. The Scandinavian Journal of Economics, 95(4), 427-443.

Rao, B. (2007). Deterministic and Stochastic Trends in the Time Series Models: A Guide for the Applied Economist, MPRA Paper No. 3580, Munich Personal RePEc Archive, University of Munich

Reid, D. M. (1988). Marketing the political product. European Journal of Marketing, 22(9), 34-47.

Rosen, S. (1986). The theory of equalizing differences. In O. Ashenfelter \& R. Layard (Eds.), Handbook of Labor Economics. Amsterdam: North-Holland.

Salve, P. \& Pandit, S. (2016). India's fastest-growing state: Meghalaya (and other North-East surprises). Business Standard, 1st Feb 2016, accessed on 25th April 2018.

Sangwan, S. S. (2016). Development setbacks in North-East India: The role of bank credit. Social Change, 46(1), 70-90.

Scammell, M. (1999). Political marketing: Lessons for political science. Political Studies, 47(4), 718-739.

Schmidt, P., \& Phillips, P. C. B. (1992). LM tests for a unit root in the presence of deterministic trends. Oxford Bulletin of Economics and Statistics, 54(3), 257-287.

Sikri, R. (2009). India's “look east” policy. Asia-Pacific Review, 16(1), $131-145$

Srikanth, H. (2016). Look east policy, sub-regional connectivity projects and North East India'. Economic and Political Weekly, 47, $45-51$.

Strazicich, M. C., Lee, J., \& Day, E. (2004). Are countries converging among OECD countries? Time series evidence with two structural breaks. Journal of Macroeconomics, 26(1), 131-145.

Toppo, H. N. (2016). India's interests in emerging subregional cooperation: Opportunities and challenges. Jadavpur Journal of International Relations, 20(1), 33-64. 
Varman, R., \& Saha, B. (2009). Disciplining the discipline: Understanding postcolonial epistemic ideology in marketing. Journal of Marketing Management, 25(7-8), 811-824.

Wring, D. (1997). Reconciling marketing with political science: Theories of political marketing. Journal of Marketing Management, 13(7), 651-663.

Ziipao, R. R. (2018). Look/Act east policy, roads and market infrastructure in North-East India. Strategic Analysis, 42(5), 476-489.
Zivot, E., \& Andrews, D. W. K. (1992). Further evidence on the great crash, the oil-price shock, and the unit-root hypothesis. Journal of Business \& Economic Statistics, 10(3), 251-270.

Publisher's Note Springer Nature remains neutral with regard to jurisdictional claims in published maps and institutional affiliations. 